\title{
Development and characterization of silver-doped sol-gel-derived borate glasses with anti-bacterial activity
}

\author{
Shiva Naseri ${ }^{\mathrm{a}}$, William C. Lepry ${ }^{\mathrm{a}}$, Vimal B. Maisuria ${ }^{\mathrm{b}}$, Nathalie Tufenkji ${ }^{\mathrm{b}}$, Showan N. Nazhat ${ }^{\mathrm{a}, *}$

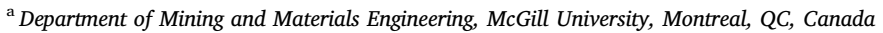 \\ ${ }^{\mathrm{b}}$ Department of Chemical Engineering, McGill University, Montreal, QC, Canada
}

\section{A R T I C L E I N F O}

\section{Keywords:}

Borate glass

Sol-gel

Silver

Antimicrobial activity

Wound healing

Bioglass

\begin{abstract}
A B S T R A C T
Borate glasses have gained attention in wound healing applications attributable to their lower chemical durability compared to silicate glasses, allowing for increased degradation rates and potentially accelerated benefits in the healing process. Recently, the sol-gel process was used to fabricate borate glasses with high specific surface areas (SSAs) leading to rapid dissolution and high reactivity when compared to their melt-quench derived equivalents. In this study, silver doped sol-gel derived borate glasses (AgBGs) were developed to impart anti-bacterial properties, thus potentially offering treatment for chronic and infected wounds. In order to optimize glass composition, the sol-gel processing route was adapted to generate two different AgBG compositional ranges; (46) $\mathrm{B}_{2} \mathrm{O}_{3}-(27) \mathrm{CaO}-(24-\mathrm{X}) \mathrm{Na}_{2} \mathrm{O}-(3) \mathrm{P}_{2} \mathrm{O}_{5}-(\mathrm{X}) \mathrm{Ag}_{2} \mathrm{O}$ where $\mathrm{X}=0,0.15,0.5$ and $1(\mathrm{~mol} \%)$ and $(60) \mathrm{B}_{2} \mathrm{O}_{3}$ (36)CaO-(4-X) $\mathrm{P}_{2} \mathrm{O}_{5}-(\mathrm{X}) \mathrm{Ag}_{2} \mathrm{O}$ where $\mathrm{X}=0,0.3,0.5$ and 1 (mol\%). It was demonstrated that the latter, sodiumfree formulation resulted in enhanced silver incorporation with high SSA $\left(237-300 \mathrm{~m}^{2} / \mathrm{g}\right)$ and small pore width (31-44 $\AA$ ) values. XRD and ATR-FTIR were used to verify the amorphous nature of the glasses and the presence of $\mathrm{BO}_{3}$ and $\mathrm{BO}_{4}$ units as the glass network former, respectively. Extent of silver ion release from the dissolution of AgBG in deionized water verified its dependency on the processing route and glass composition. Additionally, the anti-bacterial activity of AgBGs against Escherichia coli and Staphylococcus aureus was correlated with silver ion release. To the best of our knowledge, this is the first report demonstrating the potential use of anti-bacterial sol-gel derived AgBGs for potential wound healing applications.
\end{abstract}

\section{Introduction}

According to classical theory, the wound healing process consists of four main phases: hemostasis, inflammation, cell proliferation, and extracellular matrix remodeling [1]. However, in the case of chronic and infected wounds, the inflammation phase fails to reduce infection by the body's immune cells [1,2]. Therefore, in these cases, there is a need to help the body overcome infection and reduce inflammation, thus accelerating the wound healing process [1]. To this end, research has focused on biomaterial based wound dressings to help accelerate this process. Typical examples include dressings made of collagen [3], natural polymers [4], and vacuum therapy [5]. One recent approach has focused on developing bioactive and soluble glasses because of their controlled ion release which can impart anti-bacterial, anti-inflammatory and/or angiogenic properties [6].

In 1969, Dr. Larry Hench and his colleagues developed silicatebased bioactive glasses for mineralized tissue repair (e.g., bones and teeth) $[7,8]$. These glasses have the ability to bond to hard and soft tissues through the formation of a surface hydroxy-carbonate apatite (HCA) layer [7]. The most well-known and clinically used formulation is Bioglass ${ }^{\circledR}$ "45S5" [(46.1) $\mathrm{SiO}_{2}-(26.9) \mathrm{CaO}-(24.4) \mathrm{Na}_{2} \mathrm{O}-(2.6) \mathrm{P}_{2} \mathrm{O}_{5}$ (mol $\%)$ ] which has been used as fillings and bone grafts [9] as well as in dental tissues [10]. This particular glass formulation has also been studied for wound healing applications [11-13], however, due to its slow and incomplete dissolution, other, more readily soluble glasses, such as phosphates [14] and borates [15], have gained more interest.

Borate glasses are able to degrade more rapidly than silicate glasses and thus are more reactive due to their lower chemical durability $[16,17]$. These unique properties have implicated borate glasses to be used for soft tissue engineering applications such as wound healing [18]. For example, in vitro and in vivo studies have shown boron to enhance vascularization through stimulation of vascular endothelial growth factor and basic fibroblast growth factor, which is essential for angiogenesis and wound healing [19,20]. These, and other findings, have led to a melt-derived borate-based glass microfiber wound matrix (MIRRAGEN $^{\mathrm{TM}}$, ETS Wound Care LLC, USA) receiving Food and Drug

\footnotetext{
* Corresponding author.

E-mail address: showan.nazhat@mcgill.ca (S.N. Nazhat).
} 
Administration clearance as a novel wound dressing [21]. In clinical trials, MIRRAGEN ${ }^{\mathrm{TM}}$ wound dressing was shown to heal chronic wounds [21].

Since the risk of infection is greater with wounds, silver is often incorporated into a biomaterial [22] because of its anti-bacterial properties [23-25]. Additionally, a number of studies have also shown that silver has anti-inflammatory activity [26] and can facilitate the migration of fibroblasts [27,28]. However, there have only been a limited number of studies on silver doped borate glasses for medical applications, which have mainly focused on bone repair [29-32]. For example, Kamal demonstrated the potential of silver doped meltquench borate glasses $\left[(48.63) \mathrm{B}_{2} \mathrm{O}_{3}-(22.86) \mathrm{CaO}-(22.92) \mathrm{Na}_{2} \mathrm{O}-(5.59)\right.$ $\mathrm{P}_{2} \mathrm{O}_{5}$ (wt\%), prepared with addition of $1,2,4$ and $10 \mathrm{wt} \% \mathrm{Ag}_{2} \mathrm{O}$ ] for bone regeneration and anti-bacterial applications through in vitro immersion in simulated body fluid (SBF) [29]. In addition, borate glasses of the composition $(54) \mathrm{B}_{2} \mathrm{O}_{3}-(22) \mathrm{CaO}-(6) \mathrm{Na}_{2} \mathrm{O}-(8) \mathrm{K}_{2} \mathrm{O}-(8) \mathrm{MgO}-(2)$ $\mathrm{P}_{2} \mathrm{O}_{5}$ (mol\%) doped with $0.75,1$ and $2 \mathrm{wt} \% \mathrm{Ag}_{2} \mathrm{O}$, were reported by Luo et al. [32]. The incorporation of 0.75 and $1 \mathrm{wt} \% \mathrm{Ag}_{2} \mathrm{O}$, had no toxic effects against osteoblasts and fibroblasts, in vitro, while those doped with $2 \mathrm{wt} \% \mathrm{Ag}_{2} \mathrm{O}$ were found to be toxic. This study also speculated that the glasses may have anti-bacterial potential for soft tissue applications [32]. Furthermore, silver doped melt-quench borosilicate glasses of the composition (36) $\mathrm{B}_{2} \mathrm{O}_{3}-(18) \mathrm{SiO}_{2}-(22) \mathrm{CaO}-(6) \mathrm{Na}_{2} \mathrm{O}-(8) \mathrm{K}_{2} \mathrm{O}-(8) \mathrm{MgO}-(2)$ $\mathrm{P}_{2} \mathrm{O}_{5}$ (mol \%) doped with $0.05,0.5$ and $1 \mathrm{wt} \% \mathrm{Ag}_{2} \mathrm{O}$ showed anti-bacterial activity against Escherichia coli and Staphylococcus aureus [30] and a similar glass with a composition of $(36) \mathrm{B}_{2} \mathrm{O}_{3}-(18) \mathrm{SiO}_{2}-(16) \mathrm{CaO}-(6)$ $\mathrm{Na}_{2} \mathrm{O}-(16) \mathrm{CaO}-(8) \mathrm{K}_{2} \mathrm{O}-(8) \mathrm{MgO}-(2) \mathrm{P}_{2} \mathrm{O}_{5}-(6) \mathrm{SrO}$ (mol\%) doped with 0 , 0.75 , or $1.0 \mathrm{wt} \% \mathrm{Ag}_{2} \mathrm{O}$ demonstrated anti-bacterial activity against methicillin-resistant $S$. aureus applications in bone fracture fixation and bone infection [30,31].

Compared to the melt-quench method, the sol-gel process can produce glasses with enhanced textural properties which lead to faster dissolution rates and thus increased bioactivity. Furthermore, due to the lower processing temperatures, it is easier to create a wider compositional range [9]. Recently, Lepry and Nazhat reported on a series of sol-gel derived borate glasses (36-61 mol\% $\mathrm{B}_{2} \mathrm{O}_{3}$ ) based on a boron substituted 45S5 bioactive glass ["B46": (46.1) $\mathrm{B}_{2} \mathrm{O}_{3}-(26.9) \mathrm{CaO}-(24.4)$ $\mathrm{Na}_{2} \mathrm{O}-(2.6) \mathrm{P}_{2} \mathrm{O}_{5}$ (mol\%)] [33]. Compared to their melt-quench equivalent, these highly reactive glasses demonstrated $>25$ fold increase in HCA (within $3 \mathrm{~h}$ ) conversion rates in SBF. Furthermore, it has also been reported that the sol-gel method is the preferred processing route for a more homogenous incorporation of silver into a glass network [34-36]. Therefore, in this study, the processing of silver doped, sol-gel derived borate glasses (AgBGs) for potential applications in wound healing was investigated. The incorporation and integration of silver into two borate glass formulations was initially investigated by partial substitution of sodium in the B46 composition as well as a novel sodium-free composition based on $60 \mathrm{~mol} \%$ borate content. The effects of the sol-gel processing and composition on the glass properties, as well as their aqueous interactions were evaluated. Furthermore, the anti-bacterial activity of the optimized glasses was investigated and correlated with silver content and subsequent ion release.

\subsection{Materials}

Boric acid (Sigma Aldrich), calcium methoxyethoxide (20\% in methoxyethanol) (Gelest), sodium methoxide (25\% in methanol, Sigma Aldrich), triethyl phosphate (99\%, Sigma Aldrich) and silver nitrate (Fisher Scientific) were used as precursors in the sol-gel process.

\subsection{Sol-gel processing}

Table 1 provides a summary of the different compositions and processing sequences investigated in this study. AgBG-1, sequence \#1: $\mathrm{AgBGs}$ of the compositional range $(46) \mathrm{B}_{2} \mathrm{O}_{3}-(27) \mathrm{CaO}-(24-\mathrm{X}) \mathrm{Na}_{2} \mathrm{O}-(3)$ $\mathrm{P}_{2} \mathrm{O}_{5}-(\mathrm{X}) \mathrm{Ag}_{2} \mathrm{O}$ where $\mathrm{X}=0,0.15,0.5$ and $1(\mathrm{~mol} \%)$ were produced
Table 1

Overview of the sol-gel processing routes and compositions investigated in this study.

\begin{tabular}{lllllll}
\hline \multirow{2}{*}{ Glass } & ID & \multicolumn{3}{l}{ Composition (mol\%) } \\
\cline { 3 - 7 } & & $\mathrm{B}_{2} \mathrm{O}_{3}$ & $\mathrm{P}_{2} \mathrm{O}_{5}$ & $\mathrm{CaO}$ & $\mathrm{Ag}_{2} \mathrm{O}$ & $\mathrm{Na}_{2} \mathrm{O}$ \\
\hline \multirow{2}{*}{ AgBG-1 (Seq.\#1) } & B46 & 46 & 3 & 27 & 0 & 24 \\
& B46-0.15Ag & & & & 0.15 & 23.85 \\
& B46-0.5Ag & & & & 0.5 & 23.5 \\
& B46-1 Ag & & & & 1 & 23 \\
AgBG-2 (Seq.\#2) & B46-0.5 Ag & 46 & 3 & 27 & 0.5 & 23.5 \\
AgBG-3 (Seq.\#2) & B60 & 60 & 4 & 36 & 0 & - \\
& B60-0.3 Ag & & 3.7 & & 0.3 & - \\
& B60-0.5 Ag & & 3.5 & & 0.5 & - \\
& B60-1 Ag & & 3 & & 1 & - \\
\hline
\end{tabular}

following a previously reported sol-gel processing route [33]. Based on its solubility in ethanol $(\approx 11 \%)$, boric acid was initially mixed with ethanol in a Teflon beaker covered with a Teflon cap and magnetically stirred at $\sim 40{ }^{\circ} \mathrm{C}$ for $30 \mathrm{~min}$ or until clear. Next, triethyl phosphate, calcium methoxyethoxide, silver nitrate, and sodium methoxide were added at $30 \mathrm{~min}$ intervals with an additional $30 \mathrm{~min}$ of stirring after the sodium addition. The sol was then transferred into plastic vials to gel and aged for 5 days at $37{ }^{\circ} \mathrm{C}$. At the end of the ageing period, the gels were initially dried in a fume hood at room temperature for 2 days while covered with a non-transparent box to eliminate exposure to light (since silver can undergo photo-reduction of $\mathrm{Ag}^{+}$into $\mathrm{Ag}$ ) followed by further drying at $120^{\circ} \mathrm{C}$ for $48 \mathrm{~h}$ in a drying oven. The dried, as-made powders were then calcined at $400^{\circ} \mathrm{C}$ for $2 \mathrm{~h}$.

AgBG-2, sequence \#2, were of a similar compositional range (46) $\mathrm{B}_{2} \mathrm{O}_{3}-(27) \mathrm{CaO}-(24-\mathrm{X}) \mathrm{Na}_{2} \mathrm{O}-(3) \mathrm{P}_{2} \mathrm{O}_{5}-(\mathrm{X}) \mathrm{Ag}_{2} \mathrm{O}$ where $\mathrm{X}=0,0.5(\mathrm{~mol} \%)$ and were fabricated using the same route as AgBG-1 except that the addition of the calcium and silver precursors were reversed from process \#1 (i.e., silver nitrate was added before calcium methoxyethoxide). These glasses underwent the same casting, ageing, drying, and calcination steps as described for AgBG-1.

AgBG-3, sequence \#2: Silver doped, sodium free borate-based glasses of the compositional range $(60) \mathrm{B}_{2} \mathrm{O}_{3}-(36) \mathrm{CaO}-(4-\mathrm{X}) \mathrm{P}_{2} \mathrm{O}_{5}-$ (X) $\mathrm{Ag}_{2} \mathrm{O}$ where $\mathrm{X}=0.0,0.3,0.5$ and $1(\mathrm{~mol} \%)$ were produced by the sol-gel process as described in process \#2 without the addition of sodium. These glasses underwent the same casting, ageing, drying, and calcination steps as described for AgBG-1.

After calcined glasses were ground and sieved to $25-75 \mu \mathrm{m}$ particle size fraction using stainless steel wire mesh sieves and then stored in a desiccator until further use.

\subsection{Glass characterization}

\subsubsection{Particle characterization}

The average particle size of the sieved glass powders was determined using a Horiba LA-920 (ATS Scientific Ink., Canada). The specific surface area of each group $(n=3)$ sieved to $25-75 \mu \mathrm{m}$ was measured with nitrogen gas adsorption and desorption isotherms collected with a Micromeritics TriStar 3000 (Micromeritics Instrument Corporation, USA) gas sorption system. Specific surface area (SSA) values were determined using the Brunauer-Emmett-Teller (BET) method [37] while the Barrett-Joyner-Halenda (BJH) method [38], using the desorption isotherms, provided the average pore width and pore volume.

\subsection{2. $X$-ray diffraction}

X-ray diffraction (XRD) diffractograms of the glasses were analyzed with a Bruker D8 Discover X-ray diffractometer (Bruker AXSS Inc., USA) equipped with a CuKa $(\lambda=0.15406 \mathrm{~nm})$ target set to a power level of $40 \mathrm{mV}$ and $40 \mathrm{~mA}$. Using an area detector, three frames of $25^{\circ}$ were collected from 15 to 752 theta $\left({ }^{\circ}\right)$ and merged in post processing. 


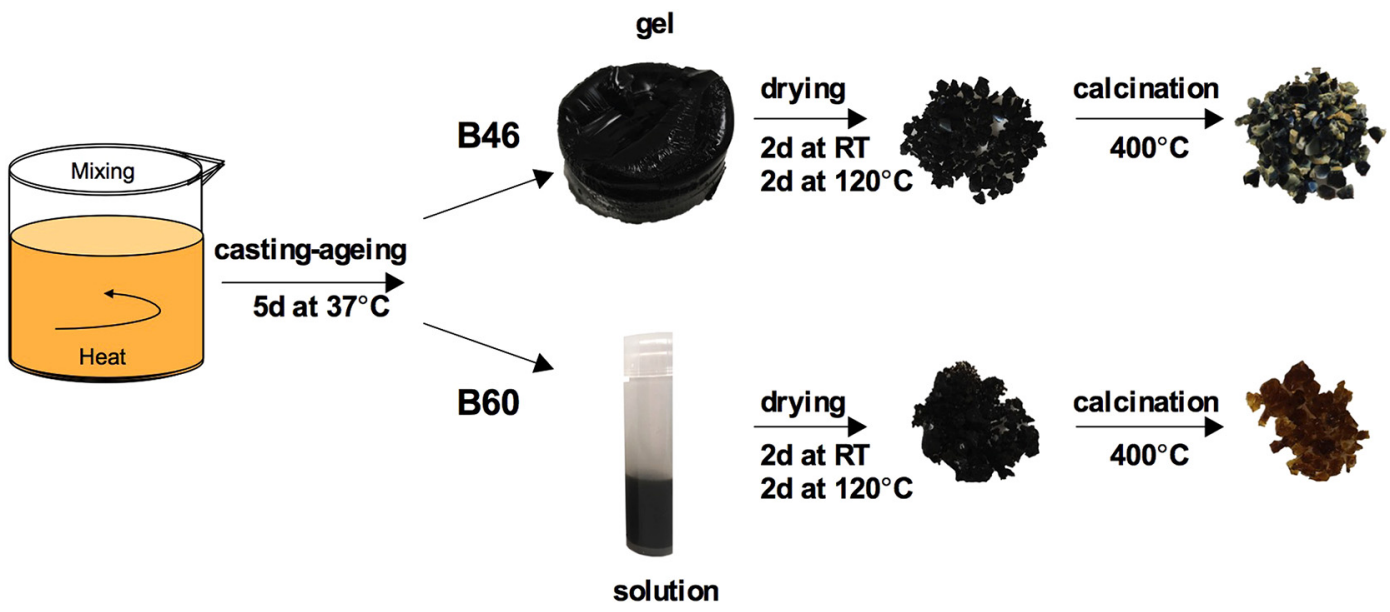

Fig. 1. An overview of the sol-gel process; B46 (AgBG-1 and AgBG-2) and B60 (AgBG-3).

Phase identification was carried out using X'Pert Highscore Plus (PANalytical, Netherlands).

\subsubsection{Attenuated total reflectance-Fourier transform infrared spectroscopy}

Attenuated total reflectance-Fourier transform infrared (ATR-FTIR) spectroscopy was carried out using a Spectrum 400 (Perkin-Elmer, USA) between 4000 and $650 \mathrm{~cm}^{-1}$ with a resolution of $4 \mathrm{~cm}^{-1}$ using 64 scans per sample. All spectra were baseline corrected and normalized to the total area surface area under absorption bands using Spectrum software (Perkin-Elmer, USA).

\subsubsection{Dynamic vapour sorption (DVS)}

The vapour sorption characteristics of AgBG particles were investigated using a DVS Intrinsic (SMS Ltd., UK), which measures mass changes $( \pm 0.1 \mu \mathrm{g}$ ) under controlled temperature and humidity. Approximately $5 \mathrm{mg}$ of AgBG particles was placed in an aluminum pan and inserted into a chamber at $37 \pm 0.05^{\circ} \mathrm{C}$. The AgBG particles were immediately exposed to $90 \% \mathrm{RH}$ for $2 \mathrm{~h}$, which was then reduced back down to $0 \% \mathrm{RH}$ for another $2 \mathrm{~h}$.

\subsubsection{Inductively coupled plasma optical emission spectrometry}

Release of silver, boron, calcium, and phosphorus ions from glass particles in deionized water (DIW) at a $1.5 \mathrm{mg}$ : $\mathrm{mL}$ ratio, were quantified using an inductively coupled plasma-optical emission spectrophotometer (ICP-OES, Thermo Scientific iCAP 6500, USA). Aliquots of $2 \mathrm{~mL}$ were filtered through a $0.2 \mu \mathrm{m}$ nylon filter and stored in a $15 \mathrm{~mL}$ falcon tube to which $4 \%(w / v)$ nitric acid (Fisher Scientific, Canada) was added followed by dilution with DIW. Serially diluted solutions of boron $(1,10,100 \mathrm{ppm})$, calcium $(1,10,100 \mathrm{ppm})$, silver $(0.05,0.5$, $5 \mathrm{ppm})$ and phosphorous $(0.05,0.5,5 \mathrm{ppm})$ were used as standards.

\subsection{Anti-bacterial assessment}

\subsubsection{Enumeration of colony forming units}

The anti-bacterial activity of the AgBGs was examined using the culturable cell counts. An overnight grown culture of $E$. coli D21 or $S$. aureus ATCC 25923 was diluted in Mueller Hinton Broth II - cation adjusted (MHB-II, Oxoid; Fisher Scientific Canada) to an $\mathrm{OD}_{600}$ of 0.05 . AgBGs at various concentrations $(0.375,0.75,1.5$ and $3 \mathrm{mg} / \mathrm{mL})$ were mixed with diluted bacterial suspension in MHB-II. Bacterial cultures exposed to AgBGs were serially diluted in phosphate-buffered saline (PBS) and plated on the surface of Luria-Bertani agar (LB - Lennox, Fisher Scientific Canada) plates (20 $\mathrm{g}$ LB powder and $15 \mathrm{~g}$ agar powder in $1 \mathrm{~L} \mathrm{DIW}$ ). The number of colonies was counted after $20 \mathrm{~h}$ of incubation at $37^{\circ} \mathrm{C}$. All measurements were carried out in triplicate on different days.

\subsubsection{Bacteria growth curves}

Bacterial growth was analyzed by directly exposing bacteria suspensions in MHB-II to AgBG particles $(0.375$ and $0.75 \mathrm{mg} / \mathrm{mL}$ ) with an initial bacterial cell density of $0.05 \mathrm{OD}_{600}$. The optical density of the suspension was then measured (at $600 \mathrm{~nm}$ ) for up to $24 \mathrm{~h}$ at $37^{\circ} \mathrm{C}$ using Tecan Infinite M200 Pro microplate reader (Tecan group Ltd., Switzerland). All measurements were carried out in triplicate.

\subsubsection{Qualitative antibacterial test}

A plate containing LB-agar (20 $\mathrm{g}$ LB powder and $15 \mathrm{~g}$ agar powder in 1 L DIW) was utilized and 1:1000 diluted bacterial culture of E. coli D21 or $S$. aureus ATCC 25923 was evenly spread on its surface. A mass of $1 \mathrm{mg}$ of AgBGs was suspended in $10 \mu \mathrm{L}$ DIW and pipetted on the surface of the agar. The zone of inhibition (clear zone) was measured after $18 \mathrm{~h}$ incubation at $37^{\circ} \mathrm{C}$ to evaluate anti-bacterial activity. All measurements were carried out in duplicate.

\subsubsection{Statistical analysis}

Data for each glass composition were analyzed for statistical significance between conditions using a Student's $t$-test at a significance level of $p<.05$.

\section{Results}

\subsection{Effect of precursor addition order on silver integration}

Fig. 1 provides an overview of the processing of sol-gel derived AgBGs based on B46 and B60. Initially, for B46-based AgBG-1 and sequence $\# 1$, the silver precursor $\left(\mathrm{AgNO}_{3}\right)$ was added after the addition of the calcium precursor and before that of the sodium precursor where the $\mathrm{pH}$ of the solution was $\sim 10$. The XRD patterns of the resultant AgBG-1 particles with 0 and $0.15 \mathrm{~mol} \%$ silver confirmed the amorphous structure of the glasses as indicated by two broad humps (Fig. 2a) [33]. However, the XRD pattern of the $0.5 \mathrm{~mol} \%$ silver sample showed a slight indication of a metallic silver phase (JCPDS 04-0783) due to the presence of a small peak near $38^{\circ} 2 \theta$. Furthermore, upon addition of $1 \mathrm{~mol} \%$ silver, this metallic silver phase was more prominent in XRD and could be observed during processing as seen by the precipitation (Fig. 2a).

ATR-FTIR spectroscopy allowed for the examination of the bonding regions in AgBG-1 (Fig. 2b). In all spectra, the presence of a peak at $720 \mathrm{~cm}^{-1}$ can be observed attributable to the B-O-B bending linkage of the $\mathrm{BO}_{3}$ units in the borate network [39]. The $\mathrm{B}-\mathrm{O}$ stretching of the boroxol ring led to the formation of a shoulder at $870 \mathrm{~cm}^{-1}$ [39]. Peaks in the range $1200-1600 \mathrm{~cm}^{-1}\left(1393\right.$ and $\left.1264 \mathrm{~cm}^{-1}\right)$ and $800-1200 \mathrm{~cm}^{-1}\left(870,942\right.$ and $\left.1017 \mathrm{~cm}^{-1}\right)$ can be attributed to the 
(a)

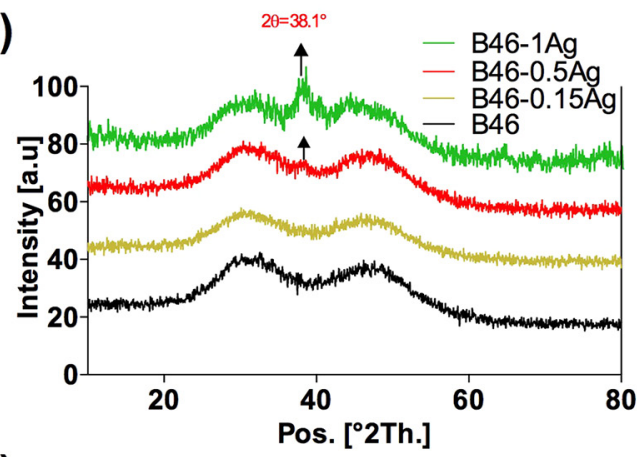

(c)

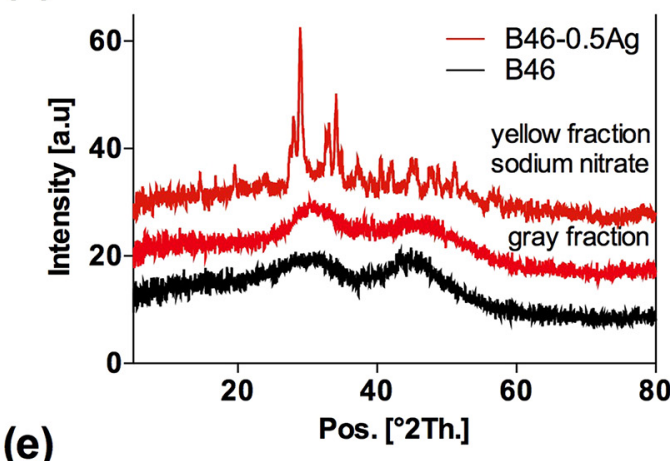

(e)

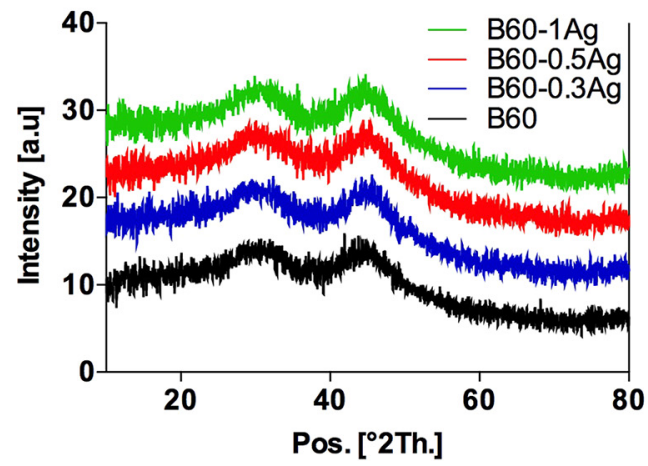

(b)

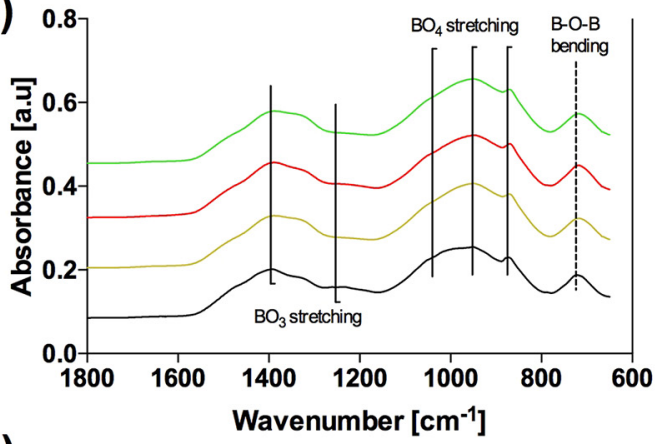

(d)

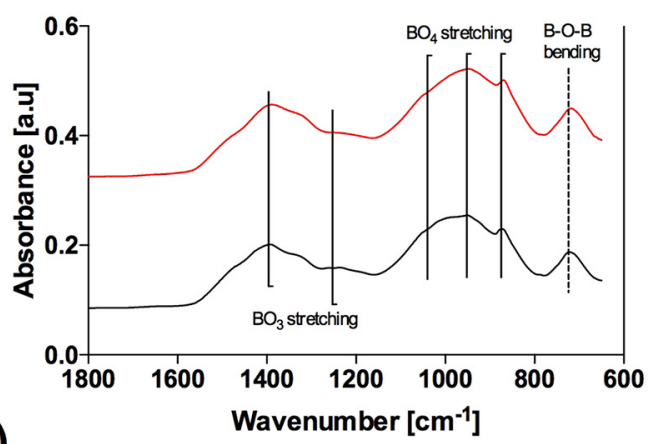

(f)

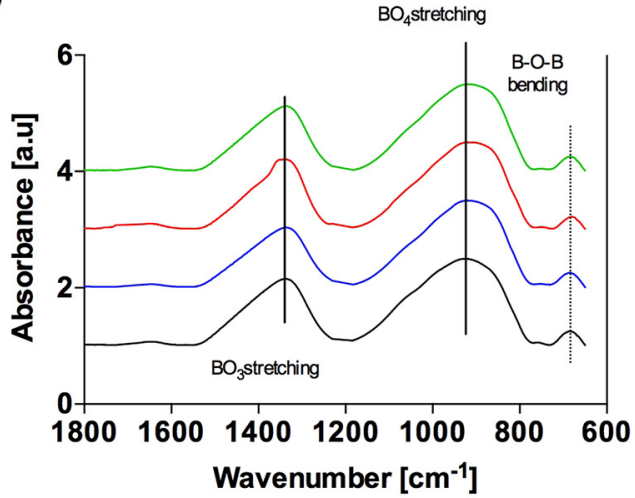

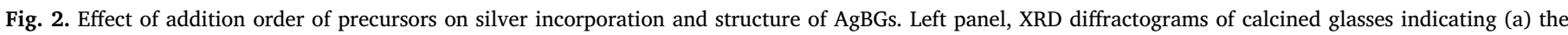

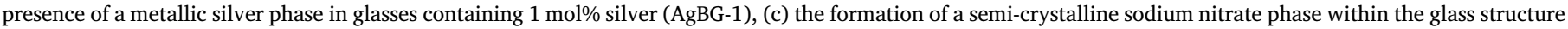

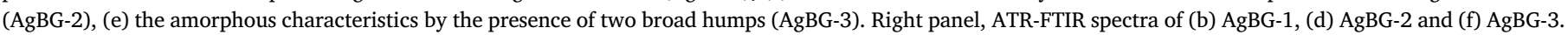
All spectra indicated typical borate bonding modes.

$\mathrm{B}-\mathrm{O}$ stretching of the $\mathrm{BO}_{3}$ structural units and $\mathrm{B}-\mathrm{O}$ stretching of $\mathrm{BO}_{4}$ structural units, respectively [39].

In an attempt to eliminate precipitation and formation of the metallic silver phase, the addition order of the silver precursor during the sol preparation was modified. Therefore, in the B46-based AgBG-2 and sequence $\# 2$, the silver precursor was added after that of the phosphorus precursor where the $\mathrm{pH}$ was $\sim 4$. This modification led to the formation of a homogenous sol without precipitation, however, upon calcination at $400^{\circ} \mathrm{C}$, a non-homogenous appearance of glass particles was observed, with yellow and dark gray fractions (Fig. 1). XRD analysis was carried out on the separated fractions and while the gray fraction was amorphous, the yellow fraction indicated a semi-crystalline sodium nitrate phase (Fig. 2c). Fig. 2d shows the ATR-FTIR spectra of AgBG-2 glasses. In all spectra, the presence of the three main regions associated with borate-based glasses was verified [39] and was in agreement with the bonding regions identified for AgBG-1 glasses (Fig. 2b).

In order to develop a homogenous glass structure, the addition of the sodium precursor was eliminated from the sol-gel processing route, while maintaining sequence \#2. The resultant B60-based sodium free sol-gel derived borate glass (AgBG-3) was similar to that recently reported by Lepry et al. [(61) $\left.\mathrm{B}_{2} \mathrm{O}_{3}-(35.6) \mathrm{CaO}-(3.4) \mathrm{P}_{2} \mathrm{O}_{5}(\mathrm{~mol} \%)\right]$ [40]. Fig. 2e and f show the XRD patterns and ATR-FTIR spectra of AgBG-3 with $0,0.3,0.5$, and $1 \mathrm{~mol} \%$ silver content, respectively. XRD diffractograms demonstrated that all glass formulations were amorphous [29]. ATR-FTIR spectra verified the presence of the three main regions associated with borate-based glasses at $800-1200 \mathrm{~cm}^{-1}$ (B-O stretching of $\mathrm{BO}_{4}$ units), $1200-1600 \mathrm{~cm}^{-1}$ (B-O stretching of $\mathrm{BO}_{3}$ units), and a peak at $\sim 720 \mathrm{~cm}^{-1}$ attributable to the $\mathrm{B}-\mathrm{O}-\mathrm{B}$ bending of $\mathrm{BO}_{3}$ units [39].

\subsection{Particle textural properties}

A summary of the average glass particle size, BET specific surface area, pore width and volume values is given in Table 2. After grinding, all glass particles had a similar particle size range with an average diameter of approximately $50 \mu \mathrm{m}$. By eliminating sodium (AgBG-3), there was a significant increase in SSA values and a reduction in pore width and volume values [40]. In general, sodium is a network modifier that disrupts the glass structure, and lowers the glass network 
Table 2

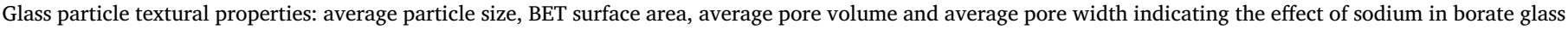
composition on textural properties $(n=3)$.

\begin{tabular}{|c|c|c|c|c|c|}
\hline Glass & ID & Particle size $(\mu \mathrm{m})$ & BET surface area $\left(\mathrm{m}^{2} / \mathrm{g}\right)$ & pore volume $\left(\mathrm{cm}^{3} / \mathrm{g}\right)$ & pore width $(\AA)$ \\
\hline \multirow[t]{3}{*}{ AgBG-1 } & B46 & $48.4 \pm 1.1$ & $75.0 \pm 1.2$ & $0.69 \pm 0.01$ & $241.6 \pm 0.6$ \\
\hline & B46-0.15Ag & $33.8 \pm 1.8$ & $53.9 \pm 1.4$ & $0.69 \pm 0.05$ & $379.9 \pm 1.2$ \\
\hline & B46-0.5 Ag & $33.2 \pm 2.5$ & $24.7 \pm 0.3$ & $0.59 \pm 0.01$ & $332.0 \pm 9.7$ \\
\hline AgBG-2 & B46-0.5 Ag & $34.1 \pm 1.7$ & $28.2 \pm 0.3$ & $0.61 \pm 0.01$ & $329.2 \pm 8.6$ \\
\hline \multirow[t]{4}{*}{ AgBG-3 } & $\mathrm{B} 60$ & $48.3 \pm 0.4$ & $240.2 \pm 2.7$ & $0.23 \pm 0.0$ & $35.3 \pm 0.03$ \\
\hline & B60-0.3 Ag & $45.7 \pm 0.6$ & $237.7 \pm 26.0$ & $0.23 \pm 0.01$ & $44.6 \pm 0.2$ \\
\hline & B60-0.5 Ag & $51.1 \pm 0.6$ & $300.2 \pm 25.6$ & $0.34 \pm 0.02$ & $33.9 \pm 0.2$ \\
\hline & $\mathrm{B} 60-1 \mathrm{Ag}$ & $47.5 \pm 0.6$ & $238.3 \pm 42.8$ & $0.25 \pm 0.01$ & $31.3 \pm 0.02$ \\
\hline
\end{tabular}

connectivity by creating non-bridging oxygens [41]. Previously, in silicate-based glass system it was demonstrated that higher glass network connectivity leads to increased surface area and reduced pore width values [42]. On the other hand, there was no correlation found between silver content and specific surface area.

\subsection{Reactivity through DVS}

Fig. 3 shows the water vapour sorption and desorption profiles of the various glass formulations during direct exposure to $90 \% \mathrm{RH}$ for $2 \mathrm{~h}$, followed by a further $2 \mathrm{~h}$ at $0 \% \mathrm{RH}$. The B46 compositional range generating AgBG-1 and AgBG-2 glasses demonstrated an increase in mass for the $2 \mathrm{~h}$ duration. However, AgBG-3 glasses demonstrated an increase in mass only within the first $10 \mathrm{~min}$, which then reached a plateau.

\subsection{Dissolution and ion release measurements in deionized water}

ICP-OES data at $24 \mathrm{~h}$ in DIW indicated that only $\sim 0.05$ and $0.15 \mathrm{ppm}$ silver was released from AgBG-1 with 0.15 and $0.5 \mathrm{~mol} \%$ silver content, respectively (Fig. 4a). Furthermore, silver release from AgBG-2 with $0.5 \mathrm{~mol} \%$ silver content was below detection limit (data not shown), which corroborated the structural analysis of the B46 compositional range, i.e., the non-homogenous formation of the glass structure. In contrast, silver release from the $\mathrm{B} 60$ compositional range was significantly higher, e.g., $\sim 3.5 \mathrm{ppm}$ silver was released from B60-0.5Ag (AgBG-3) (Fig. 4b). ICP-OES data from the B60 compositional range (AgBG-3) in DIW demonstrated the release of all three components of the base formulation (B60) (Fig. 4 c-e). There were rapid rates of release for boron and calcium, which were almost independent of silver content. Phosphorus release from AgBGs was found to decrease over time which may be due to the formation of a calcium-phosphate precipitate [43]. Fig. $4 \mathrm{f}$ shows the effect of ionic dissolution on the $\mathrm{pH}$ of DIW through the dissolution of AgBG-3 glasses, which increased to 9.

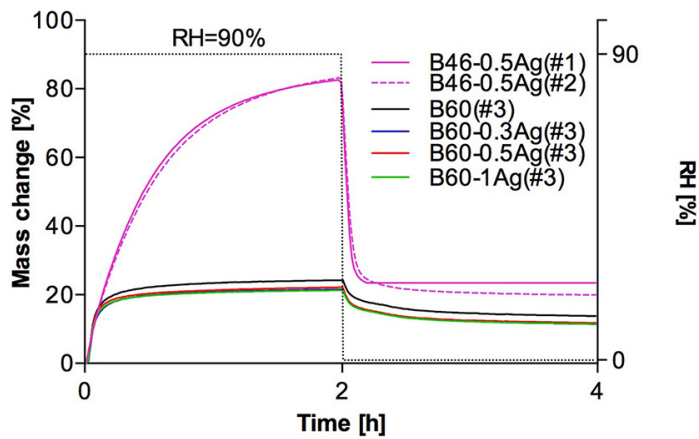

Fig. 3. Immediate aqueous interaction of AgBGs as measured through DVS. Average glass particle is $\sim 50 \mu \mathrm{m}$.

\subsection{Anti-bacterial activity of AgBGs}

The anti-bacterial activity of the B60 (AgBG-3) compositional range against $E$. coli and $S$. aureus was assessed using culturability and growth measurements (Fig. 5a, b). In terms of the culturable cell count for both strains, there was a dose-dependent response to the silver doped glasses. It was also observed that the $\mathrm{B} 60-1 \mathrm{Ag}$ was $100 \%$ effective against both bacteria, while $\mathrm{B} 60-0.5 \mathrm{Ag}$ and $\mathrm{B} 60-0.3 \mathrm{Ag}$ were less effective at the lowest concentration $(0.375 \mathrm{mg} / \mathrm{mL})$. Additionally, the results of culturability measurements suggested that AgBG-3 was more effective against $E$. coli compared to $S$. aureus. It has been reported that silver ion is less effective against $S$. aureus due to the presence of a thick peptidoglycan layer, which can limit the action of silver through the bacterial cell wall $[44,45]$. The culturable cell count method was also used to examine whether the B46 (AgBG-1) compositional range had any anti-bacterial activity, given the low silver ion release. AgBG-1 glass doped with $0.5 \mathrm{~mol} \%$ silver was compared to non-doped glass (Fig. S1). The results showed that only when a substantially higher concentration of glass particles was used (i.e., $6.4 \mathrm{mg} / \mathrm{mL}$ ), both formulations (B46 and B46-0.5Ag) demonstrated a reduction in bacterial colony counts of $E$. coli and $S$. aureus. This corroborates the ion release data (Fig. 4a), which indicated negligible silver ion release from the B46 formulation range, and the anti-bacterial activity may be attributed to the increase of local $\mathrm{pH}$ as a consequence of glass dissolution products, such as sodium (reviewed in [6,9]). For example, in the case of the B46 composition, Lepry and Nazhat [33] reported that at $24 \mathrm{~h}$ immersion in DIW, its dissolution resulted in a $\mathrm{pH}$ increase of up to $\sim 9.25$, which was attributed to the release of sodium. Furthermore, it has been reported that an increase in ionic release products also potentially results in an increase in osmotic pressure, which influence the viability of bacteria [46,47].

To further evaluate the anti-bacterial activity of the AgBG-3 compositional range, the planktonic growth of each bacteria was measured in presence of these glasses (Fig. 5c-f). At a glass concentration of $0.375 \mathrm{mg} / \mathrm{mL}$, both the non-doped and B60-0.3Ag glasses did not inhibit the growth of $E$. coli (Fig. $5 \mathrm{c}$ ). However, at $0.75 \mathrm{mg} / \mathrm{mL}$ of AgBGs, all silver containing glass formulations were found to be effective for growth inhibition of this bacterial strain (Fig. 5e). In case of $S$. aureus, both concentrations of B60-1Ag glasses were effective for growth inhibition of this bacterial strain (Fig. 5d, f). However, at a lower level of silver doping and glass concentrations, the glasses were less effective against $S$. aureus.

An agar diffusion assay was also utilized to further indicate the dose dependent anti-bacterial activity of the AgBG-3 compositional range, by measuring the zone of growth inhibition of both bacteria in the presence of glass particles (Fig. 6a). Larger diameters of inhibition zones can be observed for both bacteria in the presence of AgBGs with higher silver content. Additionally, the observed differences between both bacteria were not statistically significant $(p>0.05)$. A plot of the diameter of inhibition zone versus silver ion release (from ICP-OES data) indicates a linear correlation with $\mathrm{R}^{2}=0.952$ and $\mathrm{R}^{2}=0.899$ for $E$. coli and $S$. aureus, respectively (Fig. 6b). 
(a)
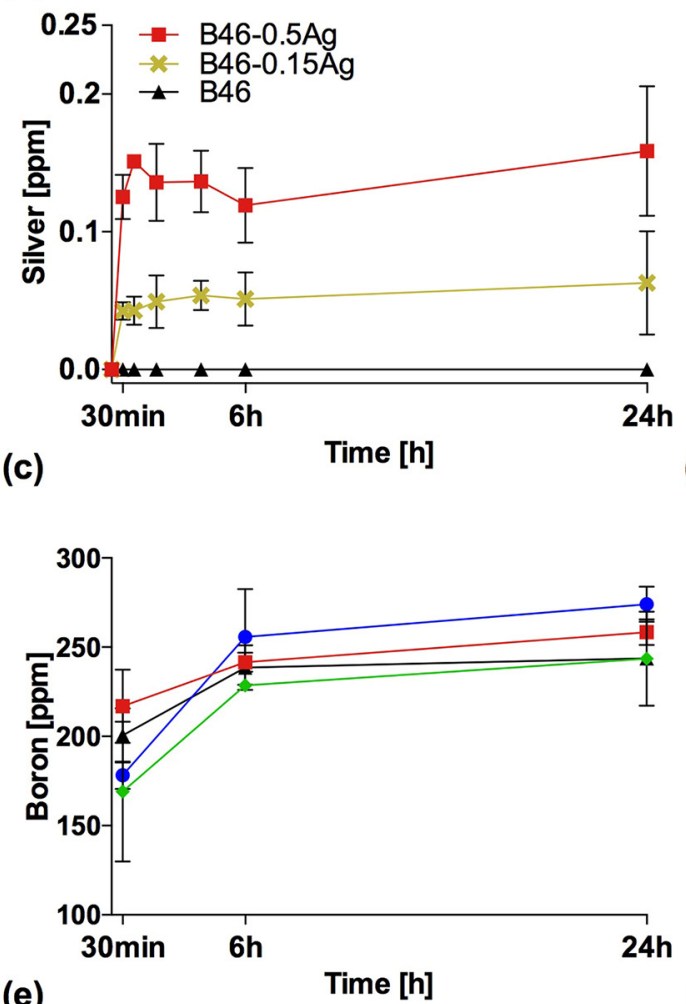

(e)

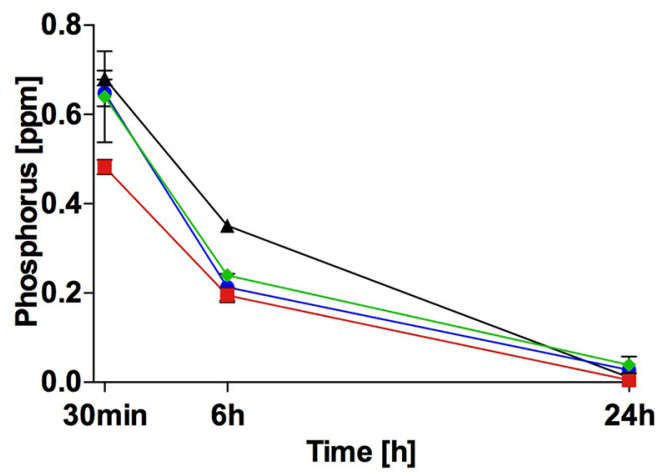

(b)
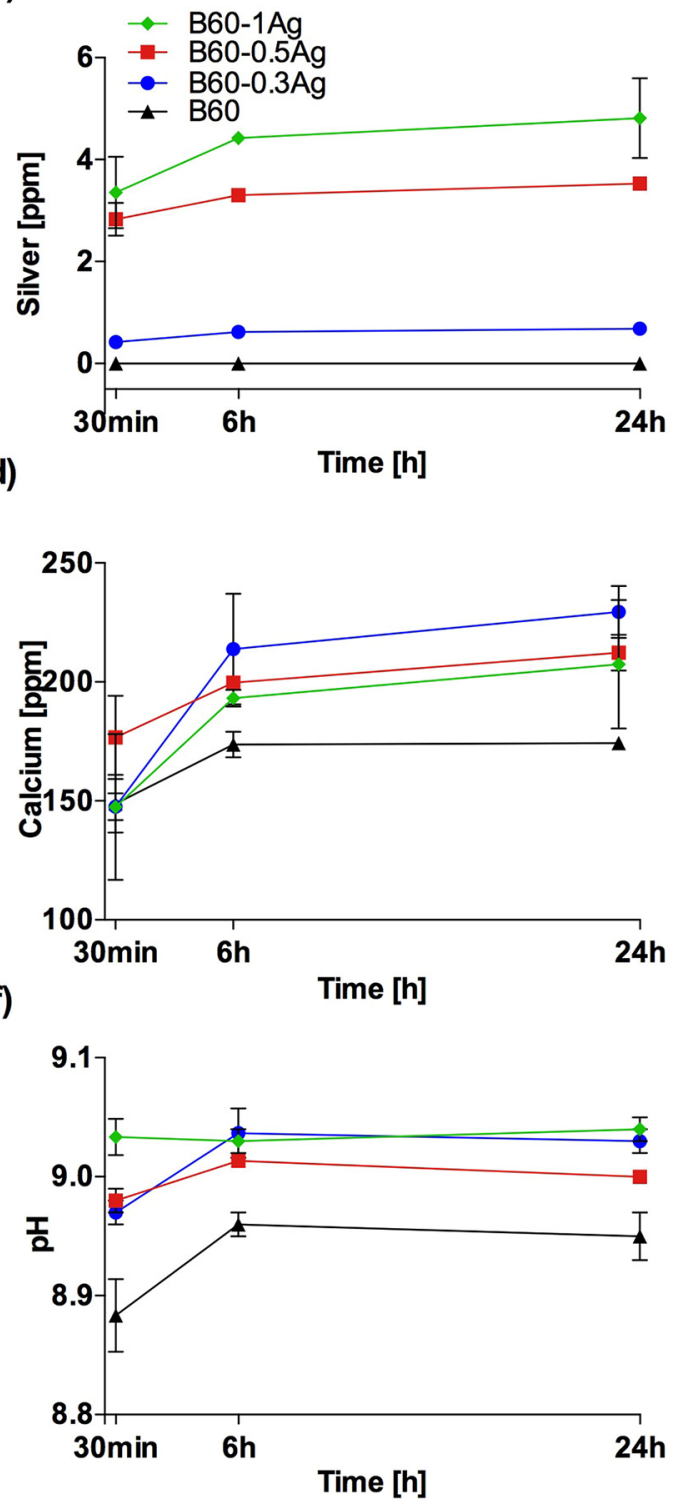

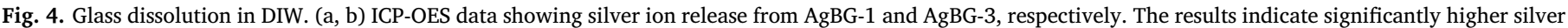

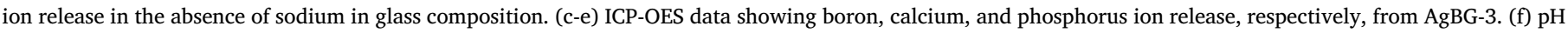
changes of DIW at $30 \mathrm{~min}$, and 6 and $24 \mathrm{~h}$ as a consequence of AgBG-3 dissolution (error bars: standard deviation: SD, $n=3$ ).

\section{Discussion}

It is well accepted that the sol-gel processing conditions such as $\mathrm{pH}$, type of precursors, and temperature, amongst other factors, directly affect each processing step as well as the final product $[48,49]$. While this was the first attempt to generate a sol-gel derived AgBG, a number of reports in literature have shown that increasing the amount of silver dopant can lead to the formation of metallic silver within phosphosilicate glasses [50-52]. For example, Simon et al., reported that the doping of melt-derived calcium phosphate glasses with $>3 \mathrm{~mol} \%$ silver, leads to the formation of precipitated metallic silver particles [50]. In another study, Delben et al., showed that sol-gel derived phosphosilicate glasses with $>3 \mathrm{~mol} \%$ silver contained metallic silver phases within the glass matrix [51]. However, Vulpoi et al., reported that even $2 \mathrm{~mol} \%$ silver causes the formation of metallic silver phase in sol-gel derived phosphosilicate glasses, and suggested that silver oxide can decompose at around $485^{\circ} \mathrm{C}$, which is above the $400{ }^{\circ} \mathrm{C}$ calcination temperature applied in this study [52].

Although there are a limited number of studies reporting on silver doped sol-gel derived glasses containing sodium oxide [53,54], in these studies, the amount of silver or sodium oxide was significantly lower compared to the other components, such as the case with the $\mathrm{NaO}_{2}$ $\mathrm{CaO}-\mathrm{SiO}_{2}$ composition doped with $0.5 \mathrm{wt} \%$ silver oxide [53] or [(58.6) $\mathrm{SiO}_{2}-(7.2) \mathrm{P}_{2} \mathrm{O}_{5} 7.2-(4.2) \mathrm{Al}_{2} \mathrm{O}_{3}-(24.9) \mathrm{CaO}-(2.1) \mathrm{Na}_{2} \mathrm{O}-(3) \mathrm{K}_{2} \mathrm{O}$ (wt\%)] with $2.1 \mathrm{wt} \%$ sodium oxide [54]. Although these studies did not state the reasons for the low silver or sodium contents, it may be that the solgel reaction is more difficult to control in the presence of a sodium precursor due to its high reactivity rates [55]. In this study, the XRD patterns suggested that the interaction of sodium and silver precursors led to sodium nitrate formation [55]. A similar finding has been reported in sodium acetate formation, confirming the high reactivity rate of the sodium precursor [55].

The presence of both $\mathrm{BO}_{3}$ and $\mathrm{BO}_{4}$ units in the FTIR spectra verified that the majority of boron formed a typical trigonal planar coordination with a fraction of four coordination formation [56] as also reported for sol-gel derived borate glasses [33]. Furthermore, an increase in glass borate content from 46 to $60 \mathrm{~mol} \%$, led to the elimination of a shoulder peak at $\sim 870 \mathrm{~cm}^{-1}$, which is characteristic of the $\mathrm{B}-\mathrm{O}$ stretching of 
(a)

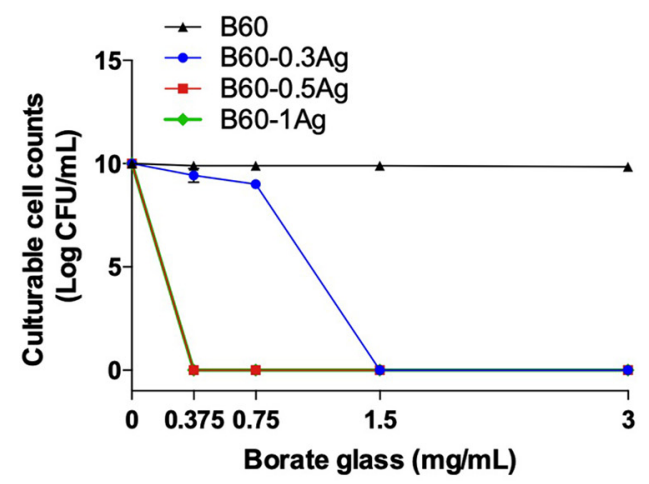

(c)

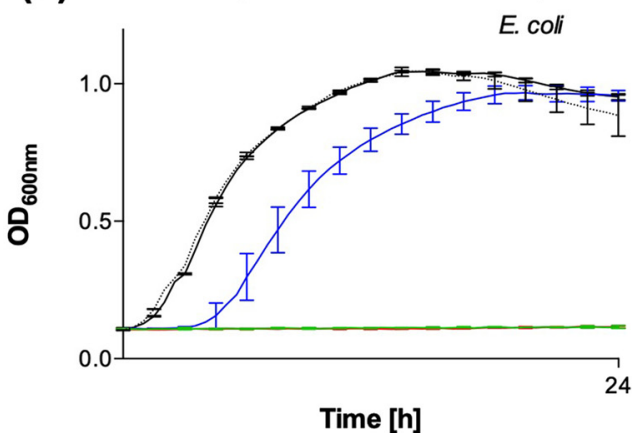

(e)

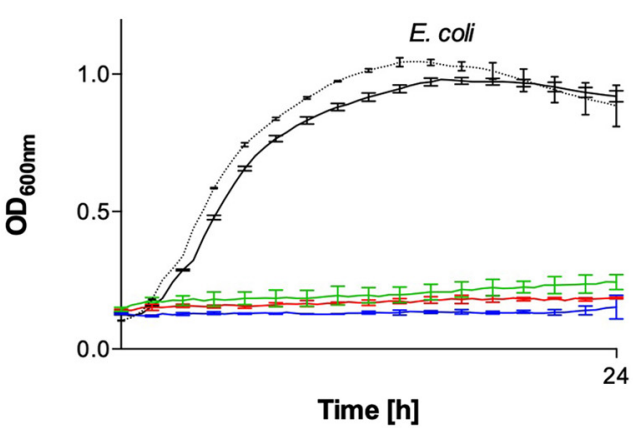

(b)

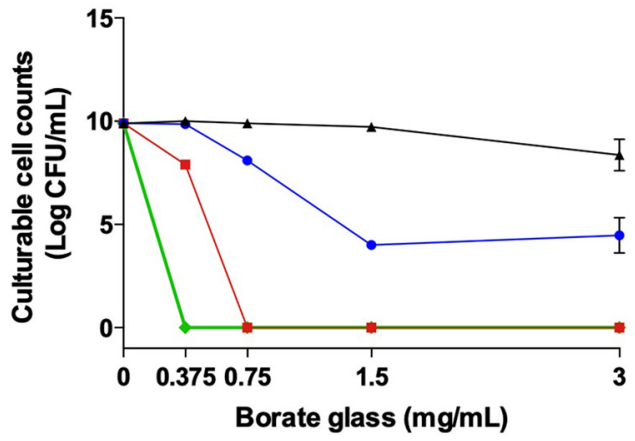

(d) $0.375 \mathrm{mg} / \mathrm{mL}$ glass

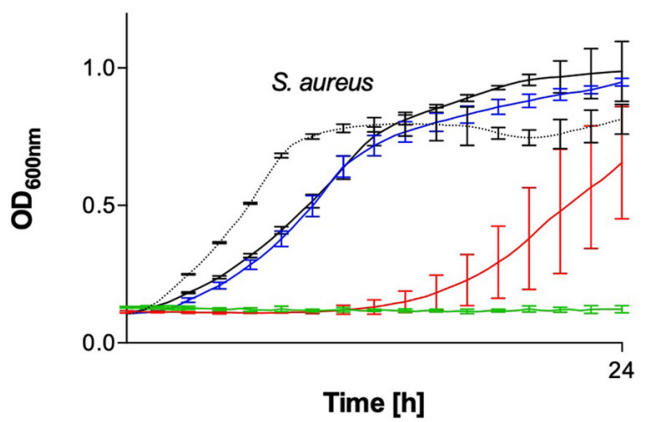

(f) $0.75 \mathrm{mg} / \mathrm{mL}$ glass

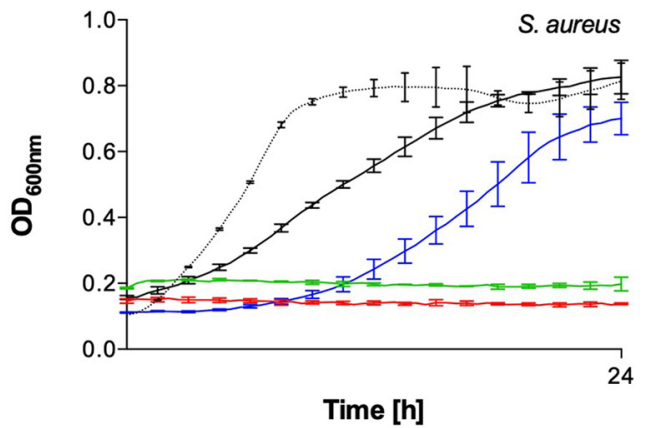

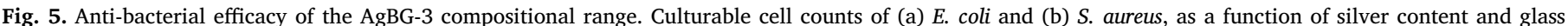

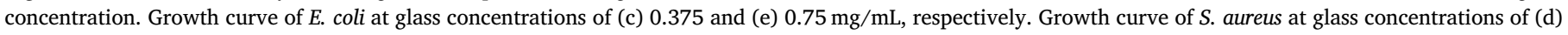
0.375 and (f) $0.75 \mathrm{mg} / \mathrm{mL}$, respectively (error bars: $\mathrm{SD}, n=3$ ).

boroxol rings as observed in the B46 [33].

To better understand the effect of composition and surface area on the reactivity of the AgBGs, DVS was used to characterize their immediate aqueous interactions. DVS, which has previously been used to examine the reactivity of bioactive glasses, $[33,57,58]$, is a gravimetric technique measuring mass change under controlled temperature and humidity. Previously, it has been reported that for sol-gel derived borate glasses, the rate and extent of mass change were more dependent on the composition rather than on glass specific surface area [33]. In this study, glasses without sodium had significantly lower values of total mass change after $2 \mathrm{~h}$ exposure to vapour sorption. On the other hand, there was no effect of either glass silver content or the glass SSA value on their vapour sorption reactivity, e.g., at the end of sorption at $90 \% \mathrm{RH}, \mathrm{B} 46-0.5 \mathrm{Ag}$ (AgBG-1) particles of $24.7 \mathrm{~m}^{2} / \mathrm{g}$ underwent a mass change of $\sim 85 \%$, and B60-0.5Ag (AgBG-3) particles of $300.2 \mathrm{~m}^{2} / \mathrm{g}$ experienced a mass change of $\sim 20 \%$. Lowering the $\mathrm{RH}$ to $0 \%$ caused a rapid decrease in mass with AgBG-1 and AgBG-2 glasses experiencing a greater extent of mass loss. These results confirm that the atomic and molecular structures have dominant roles on the chemical durability of multicomponent glasses [9,59]. In particular, the effect of sodium on the reactivity of AgBGs can be attributed to a greater presence of nonbridging oxygens and $\mathrm{OH}$ groups in the glass structure resulting in their lower chemical durability $[9,60]$.

The ion release profiles from AgBGs were in line with those of the previously reported sol-gel derived borate glasses [33]. As a result, sodium free AgBGs (AgBG-3) demonstrated higher levels of silver ion release and a homogenous glass structure with no tendency to form a precipitated metallic silver phase.

Previous studies have reported on the efficacy of silver doped silicate- and phosphate-based glasses against both Gram-negative (E. coli) and Gram-positive (S. aureus) bacteria [53,61]. For example, Bellantone et al., reported that the incorporation of $3 \mathrm{wt} \%$ silver into silicate-based 
(a)

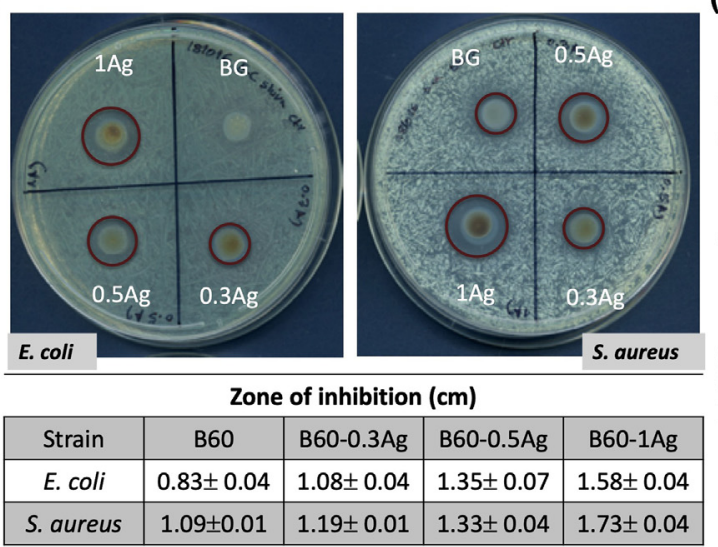

(b)

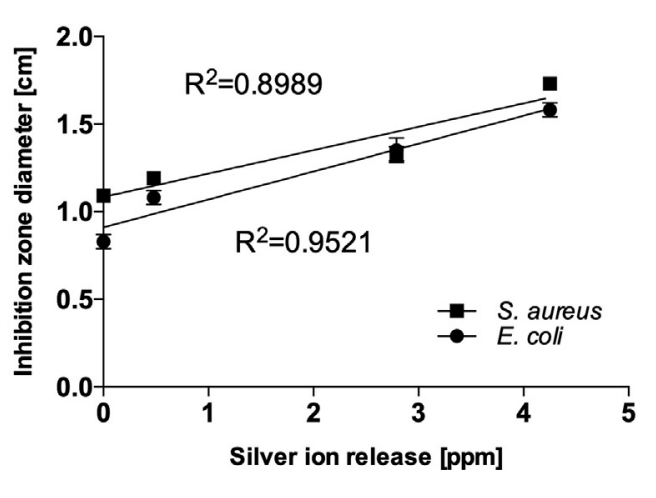

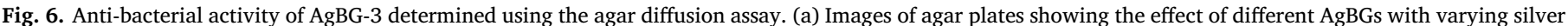
content (0, 0.3, 0.5 and $1 \mathrm{~mol} \%$ ) on $E$. coli and $S$. aureus. (b) Correlation between silver ion release and diameter of zone of inhibition (error bars: SD, $n=2$ ).

glass generated a glass with antibacterial effect against E. coli [36]. Ahmed et al., also demonstrated that silver-doped phosphate-based glasses have the ability to kill $S$. aureus and E. coli bacteria [62]. In this study, the anti-bacterial results demonstrated that the AgBG-3 compositional range inhibited the growth of both of these bacteria $[53,61]$ in a dose dependent manner, which can be correlated with silver ion release. It has been reported that silver ion can kill bacteria through different mechanisms, such as by attaching to their DNA and RNA, binding to the proteins [63], and by attaching to cell membranes and inhibiting the respiration process of bacteria [63]. Effective antibacterial concentrations of silver ion can vary from 0.1 to $20 \mathrm{ppm}$ depending on the biological condition and type of bacteria [25]. This reported range is in line with the concentrations of silver ion released from the $\mathrm{B} 60 \mathrm{AgBG}$ compositional range fabricated in this study, which holds promise for wound healing applications. Further studies will assess the efficacy of these glasses against chronic wound-related biofilms [64], and evaluate the effects of ionic dissolution products released from $\mathrm{AgBGs}$ on cellular processes in wound healing.

\section{Conclusions}

This study investigated the sol-gel processing of two silver-doped borate-based glass formulations. It was found that only the sodium-free composition, incorporating $60 \mathrm{~mol} \%$ borates, resulted in enhanced silver incorporation. Aqueous reactivity and silver ion release from the sol-gel derived glasses were found to be composition dependent. Furthermore, anti-bacterial assessment of the B60 system using E. coli and $S$. aureus indicated dose dependent activity against both Grampositive and Gram-negative bacteria and correlated with silver ion release through glass dissolution. Future work will investigate their efficacy against wound related-infection and their effect on mammalian cells for would healing applications.

Supplementary data to this article can be found online at https:// doi.org/10.1016/j.jnoncrysol.2018.11.026.

\section{Declaration of interest statement}

Drs. Nazhat and Lepry are named co-inventors on PCT/CA2015/ 000365 entitled "Borate-glass biomaterials", which describes the processing and characterization of borate-glass formulations processed through the sol-gel route.

\section{Acknowledgements}

This study was supported by NSERC, CFI and McGill University Faculty of Engineering Hatch Faculty Fellowship for S.N.N. S.N. is supported by the McGill Engineering Doctoral Award and W.C.L. is supported by The McGill EngInE Innovation Fellowship. N.T. acknowledges the Canada Research Chairs program and the Natural Sciences and Engineering Research Council of Canada.

\section{References}

[1] J.S. Boateng, K.H. Matthews, H.N.E. Stevens, G.M. Eccleston, Wound healing dressings and drug delivery systems: a review, J. Pharm. Sci. 97 (2008) 2892-2923.

[2] P. Martin, Wound healing - Aiming for perfect skin regeneration, Science 276 (1997) 75-81.

[3] C. Holmes, J.S. Wrobel, M.P. MacEachern, B.R. Boles, Collagen-based wound dressings for the treatment of diabetes-related foot ulcers: a systematic review, Diabetes Metab. Syndr. Obes. 6 (2013) 17-29.

[4] E.A. Kamoun, E.S. Kenawy, X. Chen, A review on polymeric hydrogel membranes for wound dressing applications: PVA-based hydrogel dressings, J. Adv. Res. 8 (2017) 217-233.

[5] A. Nather, S.B. Chionh, A.Y. Han, P.P. Chan, A. Nambiar, Effectiveness of vacuumassisted closure (VAC) therapy in the healing of chronic diabetic foot ulcers, Ann. Acad. Med. Singap. 39 (2010) 353-358.

[6] S. Naseri, W.C. Lepry, S.N. Nazhat, Bioactive glasses in wound healing: hope or hype? J. Mater. Chem. B 5 (2017) 6167-6174.

[7] L.L. Hench, R.J. Splinter, W.C. Allen, T.K. Greenlee, Bonding mechanisms at the interface of ceramic prosthetic materials, J. Biomed. Mater. Res. 5 (1971) 117-141.

[8] L.L. Hench, Bioceramics - from Concept to Clinic, J. Am. Ceram. Soc. 74 (1991) 1487-1510.

[9] J.R. Jones, Review of bioactive glass: from Hench to hybrids, Acta Biomater. 9 (2013) 4457-4486.

[10] L.L. Hench, The story of Bioglass, J. Mater. Sci. Mater. Med. 17 (2006) 967-978.

[11] C. Mao, C. Lin, X.F. Chen, Enhanced healing of full-thickness diabetic wounds using bioactive glass and Yunnan Baiyao ointments, J. Wuhan Univ. Technol. 29 (2014) 1063-1070.

[12] H. Li, J. He, H. Yu, C.R. Green, J. Chang, Bioglass promotes wound healing by affecting gap junction connexin 43 mediated endothelial cell behavior, Biomaterials 84 (2016) 64-75.

[13] J. Zhou, H. Wang, S.C. Zhao, N. Zhou, L. Li, W.H. Huang, D.P. Wang, C.Q. Zhang, In vivo and in vitro studies of borate based glass micro-fibers for dermal repairing, Mater. Sci. Eng. C 60 (2016) 437-445.

[14] E.A. Abou Neel, D.M. Pickup, S.P. Valappil, R.J. Newport, J.C. Knowles, Bioactive functional materials: a perspective on phosphate-based glasses, J. Mater. Chem. 19 (2009) 690-701.

[15] P. Balasubramanian, T. Büttner, V. Miguez Pacheco, A.R. Boccaccini, Boron-containing bioactive glasses in bone and soft tissue engineering, J. Eur. Ceram. Soc. 38 (2017) 855-869.

[16] X. Liu, M.N. Rahaman, D.E. Day, In vitro degradation and conversion of melt-derived microfibrous borate (13-93B3) bioactive glass doped with metal ions, J. Am Ceram. Soc. 97 (2014) 3501-3509.

[17] W. Huang, D.E. Day, K. Kittiratanapiboon, M.N. Rahaman, Kinetics and mechanisms of the conversion of silicate (45S5), borate, and borosilicate glasses to hydroxyapatite in dilute phosphate solutions, J. Mater. Sci. Mater. Med. 17 (2006) 583-596.

[18] V. Miguez-Pacheco, L.L. Hench, A.R. Boccaccini, Bioactive glasses beyond bone and teeth: emerging applications in contact with soft tissues, Acta Biomater. 13 (2015) $1-15$.

[19] A.H. Yao, D.P. Wang, W.H. Huang, Q. Fu, M.N. Rahaman, D.E. Day, In vitro bioactive characteristics of borate-based glasses with controllable degradation behavior, J. Am. Ceram. Soc. 90 (2007) 303-306.

[20] L.A. Haro Durand, A. Gongora, J.M. Porto Lopez, A.R. Boccaccini, M.P. Zago, 
A. Baldi, A. Gorustovich, In vitro endothelial cell response to ionic dissolution products from boron-doped bioactive glass in the SiO2-CaO-P2O5-Na2O system, J. Mater. Chem. B 2 (2014) 7620-7630.

[21] http://etissuesolutions.com, in, 2017.

[22] M. Diba, A.R. Boccaccini, Silver-containing bioactive glasses for tissue engineering applications, Precious Metals for Biomedical Applications, 2014, pp. 177-211.

[23] J.J. Blaker, S.N. Nazhat, A.R. Boccaccini, Development and characterisation of silver-doped bioactive glass-coated sutures for tissue engineering and wound healing applications, Biomaterials 25 (2004) 1319-1329.

[24] A.W. Wren, A. Coughlan, P. Hassanzadeh, M.R. Towler, Silver coated bioactive glass particles for wound healing applications, J. Mater. Sci. Mater. Med. 23 (2012) 1331-1341.

[25] S. Chernousova, M. Epple, Silver as Antibacterial Agent: Ion, Nanopart. Metal Angew. Chemie Int. 52 (2013) 1636-1653.

[26] K.K.Y. Wong, S.O.F. Cheung, L.M. Huang, J. Niu, C. Tao, C.M. Ho, C.M. Che, P.K.H. Tam, Further evidence of the anti-inflammatory effects of silver nanoparticles, ChemMedChem 4 (2009) 1129-1135.

[27] K. Neibert, V. Gopishetty, A. Grigoryev, I. Tokarev, N. Al-Hajaj, J. Vorstenbosch, A. Philip, S. Minko, D. Maysinger, Wound-healing with mechanically robust and biodegradable hydrogel fibers loaded with silver nanoparticles, Adv. Healthc. Mater. 1 (2012) 621-630.

[28] K. Chaloupka, Y. Malam, A.M. Seifalian, Nanosilver as a new generation of nanoproduct in biomedical applications, Trends Biotechnol. 28 (2010) 580-588.

[29] H. Kamal, Structure and physical properties of silver borate bioactive glasses, Res. J. Pharm., Biol. Chem. Sci. 5 (2014) 822-832.

[30] H. Wang, S. Zhao, X. Cui, Y. Pan, W. Huang, S. Ye, S. Luo, M.N. Rahaman, C. Zhang, D. Wang, Evaluation of three-dimensional silver-doped borate bioactive glass scaffolds for bone repair: Biodegradability, biocompatibility, and antibacterial activity, J. Mater. Res. 30 (2015) 2722-2735.

[31] W. Xiao, S.H. Luo, X.J. Wei, C.Q. Zhang, W.H. Huang, J.K. Chen, Y. Cai, Y. Rui, M.N. Rahaman, Evaluation of Ti implants coated with Ag-containing borate bioactive glass for simultaneous eradication of infection and fracture fixation in a rabbit tibial model, J. Mater. Res. 27 (2012) 3147-3156.

[32] S.-H. Luo, W. Xiao, X.-J. Wei, W.-T. Jia, C.-Q. Zhang, W.-H. Huang, D.-X. Jin, M.N. Rahaman, D.E. Day, In vitro evaluation of cytotoxicity of silver-containing borate bioactive glass, J. Biomed. Mater. Res. B Appl. Biomater. 95B (2010) $441-448$.

[33] W.C. Lepry, S.N. Nazhat, Highly bioactive sol-gel-derived borate glasses, Chem. Mater. 27 (2015) 4821-4831.

[34] J.H. Fechner, J. Zimmer, Water-Insoluble, Antimicrobial Silicate Glass and Use Thereof, in, Google Patents (2007).

[35] M. Kawashita, S. Tsuneyama, F. Miyaji, T. Kokubo, H. Kozuka, K. Yamamoto, Antibacterial silver-containing silica glass prepared by sol-gel method, Biomaterials 21 (2000) 393-398.

[36] M. Bellantone, N.J. Coleman, L.L. Hench, Bacteriostatic action of a novel fourcomponent bioactive glass, J. Biomed. Mater. Res. 51 (2000) 484-490.

[37] S. Brunauer, P.H. Emmett, E. Teller, Adsorption of gases in multimolecular layers, J. Am. Chem. Soc. 60 (1938) 309-319.

[38] L.G. Joyner, E.P. Barrett, R. Skold, The Determination of Pore volume and Area Distributions in Porous Substances. II. Comparison between Nitrogen Isotherm and Mercury Porosimeter Methods, J. Am. Chem. Soc. 73 (1951) 3155-3158.

[39] C. Gautam, A.K. Yadav, A.K. Singh, A Review on infrared Spectroscopy of Borate Glasses with Effects of Different Additives, ISRN Ceramics 2012 (2012) 17.

[40] W.C. Lepry, et al., Effect of sodium on bioactive sol-gel-derived borate glasses, J. Non-Crystalline Solids 500 (2018) 141-148.

[41] A.N. Cormack, The Structure of Bioactive Glasses and their Surfaces, Bio-Glasses, John Wiley \& Sons, Ltd, 2012, pp. 65-74.

[42] R. Li, A.E. Clark, L.L. Hench, An investigation of bioactive glass powders by sol-gel processing, J. Appl. Biomater. 2 (1991) 231-239.
[43] M. Cerruti, D. Greenspan, K. Powers, Effect of $\mathrm{pH}$ and ionic strength on the reactivity of Bioglass 45S5, Biomaterials 26 (2005) 1665-1674.

[44] W.K. Jung, H.C. Koo, K.W. Kim, S. Shin, S.H. Kim, Y.H. Park, Antibacterial activity and mechanism of action of the silver ion in Staphylococcus aureus and Escherichia coli, Appl. Environ. Microbiol. 74 (2008) 2171-2178.

[45] Q.L. Feng, J. Wu, G.Q. Chen, F.Z. Cui, T.N. Kim, J.O. Kim, A mechanistic study of the antibacterial effect of silver ions on Escherichia coli and Staphylococcus aureus, J. Biomed. Mater. Res. 52 (2000) 662-668.

[46] P. Stoor, E. Soderling, J.I. Salonen, Antibacterial effects of a bioactive glass paste on oral microorganisms, Acta Odontol. Scand. 56 (1998) 161-165.

[47] P. Stoor, E. Söderling, R. Grénman, Bioactive glass S53P4 in repair of septal perforations and its interactions with the respiratory infection-associated microorganisms Heamophilus influenzae and Streptococcus pneumoniae, J. Biomed. Mater. Res. 58 (2001) 113-120.

[48] R.L. Siqueira, O. Peitl, E.D. Zanotto, Gel-derived SiO2-CaO-Na2O-P2O5 bioactive powders: Synthesis and in vitro bioactivity, Mater. Sci. 31 (2011) 983-991.

[49] A. Lucas-Girot, F.Z. Mezahi, M. Mami, H. Oudadesse, A. Harabi, M. Le Floch, Sol-gel synthesis of a new composition of bioactive glass in the quaternary system SiO2CaO-Na2O-P2O5 Comparison with melting method, J. Non-Cryst. Solids 357 (2011) 3322-3327.

[50] V. Simon, C. Albon, S. Simon, Silver release from hydroxyapatite self-assembling calcium-phosphate glasses, J. Non-Cryst. Solids 354 (2008) 1751-1755.

[51] J.R.J. Delben, O.M. Pimentel, M.B. Coelho, P.D. Candelorio, L.N. Furini, F.A. dos Santos, F.S. de Vicente, A.A.S.T. Delben, Synthesis and thermal properties of nanoparticles of bioactive glasses containing silver, J. Therm. Anal. Calorim. 97 (2009) 433-436.

[52] A. Vulpoi, L. Baia, S. Simon, V. Simon, Silver effect on the structure of SiO2-CaOP2O5 ternary system, Mater. Sci. Eng. 32 (2012) 178-183.

[53] M. Catauro, M.G. Raucci, F. de Gaetano, A. Marotta, Antibacterial and bioactive silver-containing $\mathrm{Na} 2 \mathrm{O} \cdot \mathrm{CaO} \cdot 2 \mathrm{SiO} 2$ glass prepared by sol-gel method, J. Mater. Sci. Mater. Med. 15 (2004) 831-837.

[54] X. Chatzistavrou, E. Kontonasaki, A. Bakopoulou, A. Theocharidou, A. Sivropoulou, K.M. Paraskevopoulos, P. Koidis, A.R. Boccaccini, T. Kasuga, Development of new sol-gel derived Ag-doped biomaterials for dental applications, Materials Research Society Symposium Proceedings, 2012, pp. 41-46.

[55] Q.Z. Chen, Y.A. Li, L.Y. Jin, J.M.W. Quinn, P.A. Komesaroff, A new sol-gel process for producing Na2O-containing bioactive glass ceramics, Acta Biomater. 6 (2010) $4143-4153$.

[56] E.I. Kamitsos, Modifying Role of Alkali-Metal Cations in Borate Glass Networks, J. Phys. Chem. 93 (1989) 1604-1611.

[57] C. Stahli, M. Shah Mohammadi, K.E. Waters, S.N. Nazhat, Characterization of aqueous interactions of copper-doped phosphate-based glasses by vapour sorption, Acta Biomater. 10 (2014) 3317-3326.

[58] S. Naseri, W.C. Lepry, W. Li, K.E. Waters, A.R. Boccaccini, S.N. Nazhat, 4555 bioactive glass reactivity by dynamic vapour sorption, J. Non Crystalline Solids 432 (2016) 47-52.

[59] A. Tilocca, Structural models of bioactive glasses from molecular dynamics simulations, Proc. R. Soc. 465 (2009) 1003-1027.

[60] A. Tilocca, Structural models of bioactive glasses from molecular dynamics simulations, Proc. R. Soc. 465 (2009) 1003-1027.

[61] M. Bellantone, H.D. Williams, L.L. Hench, Broad-spectrum bactericidal activity of Ag2O-doped bioactive glass, Antimicrob. Agents Chemother. 46 (2002) 1940-1945.

[62] I. Ahmed, D. Ready, M. Wilson, J.C. Knowles, Antimicrobial effect of silver-doped phosphate-based glasses, J. Biomed. Mater. Res. A 79 (2006) 618-626.

[63] M. Rai, A. Yadav, A. Gade, Silver nanoparticles as a new generation of antimicrobials, Biotechnol. Adv. 27 (2009) 76-83.

[64] G. Zhao, M.L. Usui, S.I. Lippman, G.A. James, P.S. Stewart, P. Fleckman, J.E. Olerud, Biofilms and Inflammation in Chronic Wounds, Adv. Wound Care 2 (2013) 389-399. 